Int. J. Morphol.,

30(1):125-129, 2012

\title{
Study of Cephalic Index in Indian Students
}

\author{
Estudio del Índice Cefálico en Estudiantes Indios
}

Vaishali Kiran Yagain; Shakunthala R. Pai; Sneha G. Kalthur; Chethan, P. \& I. Hemalatha

YAGAIN, V. K.; PAI, S. R.; KALTHUR, S. G.; CHETHAN, P. \& HEMALATHA, I. Study of cephalic index in Indian students. Int. J. Morphol., 30(1):125-129, 2012.

SUMMARY: Cephalic index is important parameter for deciding race and sex of an individual whose identity is unknown. Cephalic index and head shape are greatly affected by geographical, sex, age and racial factors. Present study aimed at working out cephalic index in Indian students. 100 students were taken as subjects and head length, head breadth were measured. Indian males had mean cephalic index of 77.92 and they were mesocephalic and females had mean cephalic index of 80.85 and they were brachycephalic. The comparison was statistically significant. The data is utmost important in forensic medicine, anthropology and in genetics.

KEY WORDS: Cephalic index; Head length; Head breadth; Anthropometry.

\section{INTRODUCTION}

The human body dimensions are affected by ecological, biological, geographical, racial, sex, and age factors (Golalipour et al., 2003). Comparison of changes between parents, offspring and siblings can give a clue to genetic transmission of inherited character (Shah \& Jadhav, 2004). Anthropometric measurements especially craniofacial measurements are important for determining various head and face shapes. These anthropometrics studies are conducted on the age, sex and racial/ethnic groups in certain geographical zones (Williams et al., 1995; del Sol, 2005; Shah \& Jadhav; Golalipour et al., 2007). This helps in better understanding the frequency distribution of human morphologies and comparison of different race. The most important of cephalometric dimension are height and breadth of head that they used in cephalic index determination. Cephalic index is very useful anthropologically to find out racial and sexual differences (Shah \& Jadhav, Williams et al.).

On basis of cephalic index the head shapes classified to four international categories, that includes dolichocephaly, brachycephaly, mesocephaly and hyperbrachycephaly (Williams et al.; del Sol). Also standardized cephalometric records enable diagnostic comparison between patients and the normal population (Rabey, 1971) and are useful in pediatrics, forensic medicine, plastic surgery and oral surgery dentistry (Golalipour, 2006a). Doliocephalic people have otitis media less often than brachycephalic person (Stolovitsky \& Todd, 1990). It is also reported that indivi- dual with Alpert's syndrome are hyperbrachycephalic (Cohen \& Kreiborg, 1994).

A large number of reports exist on the adult cephalic index of Caucasians, Japanese and Australian (Kasai et al., 1993), Iran (Vojdani et al., 2009; Golalipour, 2006b; Abolhasanzadeh \& Farahani, 2003), Nigerian (Eroje et al., 2010) and Indian population such as kvangaja (Basu, 1963), Bhils and Barelias (Bhargav \& Kher, 1960, 1961) and Gujarat races of India (Shah \& Jadhav). The cranial index of Nigerian using autopsy and also living subjects was studied.

Regarding, the effect of racial, ethnic and geographical factors on head dimensions the present study was done to determine the cephalic index and the types of head shapes in students of age group $18-22$ years of Kasturba Medical College, Manipal, South Karnataka, India.

\section{MATERIAL AND METHOD}

In this study 100 medical students of Manipal University were taken as subjects of students of Kasturba Medical College Manipal. Among 100 Indian students 66 were male students and 34 were female students. The study included Indian students of all religions, with age group 
between 18-22 years in a normal healthy state. Study was carried out with protocol presentation and followed by ethical committee clearance. Instruments used in the study were manual spreading calipers and pencil. Calipers were manufactured in India by UNA and CO, scale reading up to $60 \mathrm{cms}$. Students were informed about the study design, its benefits and privacy of the data collected. Consent form was given to each student and consent was taken.

Students were asked to sit in a relaxed state, straight and looking forward. Head measurements, which were determined by spreading caliper, were included:

Head length $=$ Summit of glabella to inion (occipital point). Head breadth $=$ maximum horizontal diameter.

All the measurements have been taken following the techniques of Martin \& Saller (1957) and Singh \& Bhasin (1989). Head length and head breadth was classified according to Martin \& Saller (Table I).

Cephalic index was calculated using the formulae:

$$
\text { Cephalic index }=\frac{\text { Head breadth }}{\text { Head length }} \times 100
$$

Above index was determined on the basis of international descriptions (Williams et al.) (Table II).

Table I. Head length and head breadth was classified according to Martin \& Saller (1957).

\begin{tabular}{llcc}
\hline & & Males range $(\mathbf{c m})$ & Females range \\
\cline { 3 - 4 } $\begin{array}{l}\text { Classification } \\
\text { of head length }\end{array}$ & Very Short & $\mathrm{X}-16.9$ & $\mathrm{X}-16.1$ \\
& Short & $17-17.7$ & $16.2-16.9$ \\
& Medium & $17.8-18.5$ & $17-17.6$ \\
& Long & -19.3 & 17.718 .4 \\
& Very long & $>19.4$ & $>18.5$ \\
Classification & Very narrow & $\mathrm{X}-13.9$ & $\mathrm{X}-13.4$ \\
of head & Narroadth & $14-14.7$ & $13.5-14.1$ \\
& Medium & $14.8-15.5$ & $14.2-14.9$ \\
& Broad & $15.6-16.3$ & $15-15.7$ \\
\hline
\end{tabular}

Table II. Index was determined on the basis of international descriptions (Williams et al., 1995).

\begin{tabular}{lc}
\hline Head shape & Range of cephalic index \\
\hline Dolicocephalic & $<74.9$ \\
Mesocephalic & $75-79.9$ \\
Brachycephalic & $80-84.9$ \\
Hyperbrachycephalic & $>85$ \\
\hline
\end{tabular}

\section{RESULTS}

In the present study cephalic index was calculated using the standard formulae and determined on the basis of international descriptions Williams et al. All measurements were expressed in centimeters. The data represents the mean and standard deviation of the actual values of head length, head breadth and cephalic index of all subjects. The results were computed and analyzed statistically as shown in Table III and IV.

In males head length ranged from $17.5 \mathrm{~cm}$ to $20.5 \mathrm{~cm}$ with mean of $18.76 \mathrm{~cm}$ and head breadth from $13.5 \mathrm{~cm}$ to $16.3 \mathrm{~cm}$ with mean of $14.59 \mathrm{~cm}$. In females head length ranged from $16.3 \mathrm{~cm}$ to $19.5 \mathrm{~cm}$ with mean of $17.67 \mathrm{~cm}$ and head breadth ranged from $12.3 \mathrm{~cm}$ to $15.5 \mathrm{~cm}$ with a mean of $14.17 \mathrm{~cm}$. Head length and head breadth were classified according to Martin \& Saller and our results showed that head length in Indian males had majority of medium type with $45 \%$, followed by very long and long with $32 \%$ and $17 \%$ respectively. Least common was short type with $6 \%$ and with absence of very short type. Whereas head length in female's majority had medium type with $41 \%$, followed by very long and long type with $29 \%$ and $12 \%$ respectively with least frequency of short with $18 \%$ and none as very short. Head breadth in males showed majority with narrow type $39 \%$, followed by medium $35 \%$ and very narrow with $20 \%$. In females medium type was commonest $50 \%$, followed by narrow $35 \%$, very narrow as $9 \%$ and broad type $6 \%$.

The mean cephalic index in males was recorded to be $77.92 \pm 5.2$. Head shape was classified by cephalic index in which dominant type was dolicocephalic (33\%) and brachycephalic $(33 \%)$, followed by $27 \%$ mesocephalic and $6 \%$ hyperbrachycephalic. The mean cephalic index in female was $80.85 \pm 7.71$ which showed that majority were brachycephalic (33\%), with $29 \%$ each of dolicocephalic and hyperbrachycephalic and least common mesocephalic (9\%). Comparison of percentage of male and female cephalic index is depicted in Graph 1.

\section{DISCUSSION}

In respect to the variation of head shape in various races and geographical zones, we 
Table III. Results of cephalic index Indian males ( $\mathrm{n}=66)$.

\begin{tabular}{lccc}
\hline & Minimum & Maximum & Mean \\
\hline Head length & 17.5 & 20.5 & 18.76 \\
Head width & 13.5 & 16.3 & 14.59 \\
Cephalic index & 69.23 & 88.88 & 77.92 \\
\hline
\end{tabular}

Table IV. Results of cephalic index Indian females $(n=34)$.

\begin{tabular}{lccc}
\hline & Minimum & Maximum & Mean \\
\hline Head length & 16.3 & 19.5 & 17.67 \\
Head width & 12.3 & 15.5 & 14.17 \\
Cephalic index & 65.07 & 93.75 & 80.85 \\
\hline
\end{tabular}

believe that hereditary factor primarily affects the head shape; however environment has a secondary effect on it. It must be remembered that the reaction to a given environment represents the interaction of the genotype of the population being studied with the environment (Jordaan, 1976). The present study reports the anthropometrical variations in cephalic index in Indian medical students taking head length, head breadth, cephalic index as parameters.

When compared to Shah \& Jadhav the mean head lengths in male corresponds but in females present study shows higher value $(17.67 \mathrm{~cm})$ than Gujarati females $(16.5$ $\mathrm{cm})$. Also the head breadth in both males and females when compared to Gujarati was almost similar. In present study head length varies from medium to long in both the sexes where very short head length was absent. But short head length was commonest variety seen in Onges (Pandey, 2006). Also regarding head breadth medium to narrow was observed in both sexes with high frequency which was similar with Onges study (Pandey).

In the present study mean Cephalic index of males was 77.92. This finding was slightly higher than Bhils study with 76.98 (Bhargava \& Kher, 1960). But lower than Barelas with 79.80 (Bhargava \& Kher, 1961) and Gujarati males with 80.42 (Shah \& Jadhav) of Indian group. Also when compared with other groups such as European (81.19), North of Europe (79.72) (Garcia \& Lips, 1986b), Chile (81.51) (Garcia \& Lips, 1986a), Iran 80.4 (Golalipour et al., 2007), south of Iran (82.4) (Vojdani et al.), Ijaw (80.98) and Igbo (79.04) tribes community (Oladipo \& Olotu, 2006), Baysela state, Nigeria (73.68) (Eroje et al.) it was lower.

In our study, dominant type of head shape in males was dolicocephalic (33\%) and brachycephalic (33\%) but the mean cephalic index was 77.92 (mesocephalic). This finding of dolicocephalic was similar to study done on Indian males (Bhatia et al., 1995) in which 58.5\% of population was dolicocephalic, but not similar with the study by del Sol in
Chile (66\%), Bhasin (2006), Shah \& Jadhav in Gujarati (41\%) which showed Mesocephalic head shape was common. The dolicocephalic shape was a rare type found in Iranian group about 7.5\% in South Iran (Vojdani et al.), 1.5\% in North Iran (Golalipour, 2006b), 9\% in Tehran (Abolhasanzadeh \& Farahani), 7\% in Indian gujarati (Shah \& Jadhav) and about 2\% in IX Region of Chile (del Sol). Also in our study, the other dominant type of head shape was Brachycephalic (33\%) which is similar to study done on Turkman males (42.4\%) in North Iran (Golalipour et al., 2007) and Tehran - Iran (36.6\%) (Abolhasanzadeh \& Farahani).

In the present study least common type of male head shape was hyperbrachycephalic (6\%). But this was dominant type observed in on Fars males in North of Iran (52\%) (Golalipour, 2006b), South Iran (34.3\%) (Vojdani et al.).

The Cephalic index of Indian females in present study was 80.85 . This finding was lower than Nakashima (1986) study with 87 , Golalipour (2006a) study on native Fars group with 85, Turkman group 82.8 in North of Iran (Golalipour, 2006b), Shah \& Jadhav from India with 81.20. But higher than Abolhasanzadeh \& Farahani study in Tehran- center of Iran with 75, Buretic'-Tomljanovic' et al. (2004) study in Croatia with 79.23, Ijaw (78.24) and Igbo (76.83) tribes community (Oladipo \& Olotu), Baysela state, Nigeria with 72.24 (Eroje et al.).

In females the dominant type of head shape was brachycephalic (33\%). It is similar to other study in TehranIran $(42.7 \%)$ (Abolhasanzadeh \& Farahani), South of Iran $(42.5 \%)$ (Vojdani et al.), and Shah \& Jadhav study in India $(49 \%)$. But in a study of Fars female, North Iran hyperbrachycephalic (53.6\%) (Golalipour, 2006a) was dominant which in our present study was $29 \%$.

In our study rare type of head shape was mesocephalic (9\%) which was not similar to other study such as TehranIran (9.9\%) (Abolhasanzadeh \& Farahani), Fars $(0.1 \%)$ and Turkman, North of Iran (0.5\%) (Golalipour, 2006a), South Iran $(4.84 \%)$ (Vojdani et al.), and Shah \& Jadhav in India $(0.3 \%)$ where dolicocephalic was rare.

This study showed that the mean cephalic index of female was significantly higher than those of male $(\mathrm{p}=0.025)$. The mean cephalic index of this study was $78.92 \pm 6.31$ which says that the dominant head shape among Indians was brachycephaly which was lower than Shah \& Jadhav study in India with 80.42, Bhargava \& Kher (1961) Berelas of Central India 79.80, Chile (80.42) by del Sol, Fars males with 84.8 (Golalipour, 2006b), Fawehinmi et al. (2008) study in Port arcourt, Nigeria with 79.80. 
But the Cephalic index was higher when compared to Abolhasanzadesh \& Farahani study in Tehran - Iran with 75, Bhargav \& Kher (1960) for Bhils of Central India 76.98, Eroje et al. Ogbia, Nigeria with 72.96 .

This shows that there is tendency towards brachycephalisation. Comparing previous records of cephalic index with recent work proves tendency towards "brachycephalisation" - evidence of continuous growh of brain more in the lateral direction (Shah \& Jadhav). Also, in tropical zones head form is longer (dolichocephalic), but in temperate zones the head form is more round (mesocephalic or brachycephalic) (Bharati et al., 2001). Since India is in the partly in temperate and tropical zone, the present classification shows tendency to brachycephalization from dolicocephalic.
The variations of head shape may be due to hereditary factor or environmental which may act as secondary effect (Golalipour et al., 2007). The kind of diet taken could also play a role in influencing the dominant head shape. Head shapes can also change from one generation to the other. For instance, in the first generation of Japanese immigrants in Hawaii it was noticed that they had an increased head breadth, a decreased head length and a higher cephalic index than their parents (Heravi \& Zieaee, 2002).

With the help of above statistics the sex as well as race of the deceased can be determined accurately. This knowledge is of immense importance to anthropologists as well as forensic science experts.

YAGain, V. K.; PAI, S. R.; KAlTHUR, S. G.; CHETHAN, P. \& HEMAlatha, I. Estudio del índice cefálico en estudiantes Indios. Int. J. Morphol., 30(1):125-129, 2012.

RESUMEN: El índice cefálico es un parámetro importante para determinar la raza y el sexo de un individuo cuya identidad es desconocida. El índice cefálico y la forma de la cabeza se ven afectados en gran medida por la geografía, el sexo, la edad y factores raciales. El presente estudio tuvo como objetivo la elaboración de índice cefálico de estudiantes indios. Cien estudiantes fueron tomados como sujetos de estudio, y fue medida la longitud y amplitud de la cabeza. Los hombres indios tuvieron una media del índice cefálico de 77,92 correspondiente a individuos mesocéfalos, mientras que las mujeres tuvieron una media del índice cefálico de 80,85 siendo braquicéfalas. La comparación fue estadísticamente significativa. Los datos obtenidos son de importancia para la medicina forense, la antropología y la genética.

PALABRAS CLAVE: Índice cefálico; Longitud de la cabeza; Amplitud de la cabeza; Antropometría.

\section{REFERENCES}

Abolhasanzadeh, A. \& Farahani, M. R. Standarded international classification of head shapes of 22-24 years old in Tehran. $J$. of Research in Medicine, 26:281-5, 2003.

Basu, A. Anthropometry of the kayasthas of Bengal. J. Anat. Soc. Ind., 3:20-5, 1963.

Bharati, S.; Som, S.; Bharati, R. \& Vasulu, T. S. Climate and head form in India. Am. J. Hum. Biol, 13:626-34, 2001.

Bhasin, M. K. Genetics of Castes and Tribes of India: Somatometry. Int. J. Hum. Genet., 6:323-56, 2006.

Bhargava, I. \& Kher, G. A. An anthropometric study of Central India Bhils of Dhar district of Madhya Pradesh. J. Anat. Soc. India, 9:14-9, 1960.

Bhargava, I. \& Kher, G. A. A comparative anthropometric study of Bhils and Barelas of Central India. J. Anat. Soc. India, 10:2633, 1961.

Bhatia, M.; Thin, J.; Debray, H. \& Cabanes, J. Etude anthropologique et genetique de la population du nord de lTnde.
Bull Et Mem. Soc. d'Anthrop. de Paris, 10:199-213, 1955.

Buretic'-Tomljanovic', A.; Ristic', S.; Brajenovic'-Milic', B.; Ostojic', S.; Gombac, E. \& Kapovic', M. Secular change in body height and cephalic index of Croatian medical students (University of Rijeka). Am. J. Phys. Anthropol., 123:91-6, 2004.

Cohen, M. \& Kreiborg, S. Cranial size and configuration in the Apert syndrome. J. Craniofac. Genet. Dev. Biol., 14:153-62, 1994.

Del Sol, M. Cephalic index in a group of mapuche individuals in the IX Region of Chile. Int. J. Morphol., 23:241-6, 2005.

Eroje, M. A.; Fawehinmi, H. B.; Jaja, B. N. \& Yaakor, L. Cephalic index of Ogbia tribe of Bayesla state. Int. J. Morphol., 28:38992, 2010.

Fawehinmi, H. B.; Osunwoke, A. E.; Ligha, A. E. \& Okoh, P. D. A comparative study on the cephalic indices of normal growing children and children with sickle cell anaemia in Port Harcourt. J. Exp. \& Clin. Anat., 7:27-9, 2008. 
Garcia, H. F. \& Lips, M. W. Contribución al estudio del indice cefálico en chilenos. An. Anat. Normal, 4:120-3, 1986a.

Garcia, H. F. \& Lips, M. W. Variacioness del indice cefálico chilenos según ascendencia. An. Anat. Normal, 4:117-9, 1986b.

Golalipour, M. J. The Effect of Ethnic Factor on. Cephalic Index in 17-20 Years Old Females of North of Iran. Int. J. Morphol., 24:319-22, 2006a.

Golalipour, M. J. The variation of head shapes in 17-20 years old native Fars male in Gorgan-North of Iran. Int. J. Morphol., 24:187-90, 2006b.

Golalipour, M. J.; Haidari, K.; Jahanshahi, M. \& Frahani, M. R. The shapes of head and face in normal male newborns in South-East of Caspian Sea (Iran-Gorgan). J. Anat. Soc. India, 52:28-31, 2003.

Golalipour, M. J.; Jahanshahi, M. \& Haidari, K. Morphological evaluation of head in Turkman males in Gorgan-North of Iran. Int. J. Morphol., 25:99-102, 2007.

Heravi, F. \& Zieaee, H. Assessing the importance of cephalic and facial indices in a group of 12 year old boys in Mashhad. Beheshti Univ. Dent. J., 20:119-24, 2002.

Jordaan, H. V. Neonatal and maternal cranial form. S. Afr. Med. J., 4:2060-8, 1976.

Kasai, K.; Richards, L. C. \& Brown, T. Comparative-Study of Craniofacial Morphology in. Japanese and Australian Aboriginal Populations. Hum. Biol., 65:821-34, 1993.

Martin, R. \& Saller, K. Lehrbuch der Anthropologie, Dritte Auflage. Stuttgart, Gustav Fischer Verlag, 1957. Vol. II.

Nakashima , T. Brachycephalization in the head form of school girls in north Kyushu. Sangyo. Ika Dainguku Zussshi, 5:4114, 1986.

Oladipo, G. S. \& Olotu, J. Anthropometric comparison of cephalic indices between the Ijaw and Igbo tribes. Global Jnl. Pure and Applied Sciences, 12:137-8, 2006.

Pandey, A. K. Cephalo-facial Variation Among Onges. Anthropologist, 8:245-9, 2006.

Rabey, G. P. Craniofacial morphanalysis. Proc. R. Soc. Med., 64:103-11, 1971.

Shah, G. V. \& Jadhav, H. R. The study of cephalic index in students of Gujarat. J. Anat. Soc. India, 53:25-6, 2004.

Stolovitsky, J. P. \& Todd, N. W. Head shape and abnormal appearance of Tympanic membrane. Otolaryngol. Head Neck Surg., 102:322-5, 1990.
Singh, I. P. \& Bhasin, M. K. Anthropometry. Delhi, Kamla-Raj Enterprises, 1989.

Vojdani, Z.; Bahmanpour, S.; Momeni, S.; Vasaghi, A.; Yazdizadeh, A.; Karamifar, A.; Najafifar, A.; Setoodehmaram, S. \& Mokhtar, A. Cephalometry in 14-18 year old girls and boys of Shiraz-Iran high school. Int. J. Morphol., 27:101-4, 2009.

Williams, P.; Dyson, M.; Dussak, J. E.; Bannister, L. H.; Berry, M.M.; Collins, P. \& Ferguson, M. W. J. Gray's anatomy. In. Skeletal system. 38th Ed. London, Elbs with Churchill Livingston, 1995. pp. 607-12.

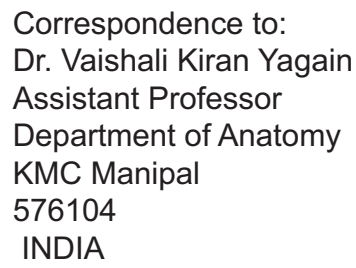

Email: vaishalikiran31@gmail.com

Received: 02-04-2011

Accepted: 14-07-2011 